\title{
CLAYTONIA PERFOLIATA (MONTIACEAE) \\ NEWLY REPORTED IN ARKANSAS, U.S.A.
}

\author{
Adam C. Schneider \\ Hendrix College \\ 1600 Washington Ave \\ Conway, Arkansas 72032, U.S.A. \\ schneider@hendrix.edu
}

ABSTRACT

This is the first record of the western American species Claytonia perfoliata Don ex Willd. (Montiaceae) in Arkansas, and the first record of this species in a natural, undeveloped area east of the Great Plains. A key to species of Claytonia in Arkansas is included.

\section{RESUMEN}

Se cita la especie americana occidental Claytonia perfoliata Don ex. Willd. (Montiaceae) por primera vez de Arkansas, y por primera vez en una zona natural (no urbanizada) al este de las Grandes Llanuras. Se incluye una clave de las tres especies de Claytonia en Arkansas.

KEY WoRDS: Claytonia perfoliata, noteworthy collection, new record

In the spring of 2019, I discovered a robust individual of Claytonia perfoliata Don ex Willd. (miner's lettuce, Montiaceae), growing on a sandstone bluff off-trail in Cove Creek Natural Area in central Arkansas (Fig. 1). Claytonia perfoliata is native to the western United States and Canada, Mexico, and Guatemala, and naturalized throughout Europe and New Zealand (Miller 2003). Compared to the two other species of Claytonia previously known from Arkansas and also present at Cove Creek, C. virginica L. and C. arkansana Yatsk., R. Evans, $\&$ Witsell, this species is unique with its annual life cycle, flowers less than $10 \mathrm{~mm}$ in diameter, large, perfoliate cauline leaves, rhombic to deltate basal leaves, and unibracteate inflorecence.

This plant was in flower and fruit on the date of collection (27 Apr 2019), but only vegetative during previous visits (9 Feb and 3 Mar). Associates include Heuchera villosa var. arkansana (Rydb.) E.B. Sm. and Toxicodendron radicans (L.) Kuntze growing adjacent on sandstone, and Claytonia virginica growing at the base of the bluff on a sandy slope. The seed source for this collection is unknown, but C. perfoliata is commonly foraged as an edible green and is sometimes cultivated for this reason. It is possible that seeds of C. perfoliata were transported down Cove Creek during a winter flood given that no individuals were seen closer to footpaths. Voucher specimens of this plant were deposited at the Arkansas Natural Heritage Commission and Hendrix College.

Voucher Specimen: ARKANSAS. Faulkner Co.: Cove Creek Natural Area, east-facing sandstone bluffs ca. $0.5 \mathrm{~m}$ above the sandy floodprone banks of Cove Creek and ca. $5 \mathrm{~m}$ above the water line near bottomland hardwood forest, elev. ca. $300 \mathrm{~m}, 35.292^{\circ} \mathrm{N}, 92.478^{\circ} \mathrm{W}, 27 \mathrm{Apr}$ 2019, Schneider 1063 (ANHC, HXC).

To date, I am aware of four voucher collections of C. perfoliata east of the Great Plains. One specimen was growing near greenhouses at Missouri Botanical Garden (MacDougal 6085, MO). Two collections were made in the same year from a lawn at Stone Mountain Park, Georgia (Moore 2494, GA; Moore 2498, TENN, USCH). A third was collected from a garden in Jefferson, New Hampshire (Wellman 16589, NEBC). Several observations of this species east of the Great Plains in urban environments or in the vicinity of cultivated plants have also been reported via iNaturalist (2019). This specimen from Cove Creek is the first record of C. perfoliata from Arkansas (Gentry et al. 2013; Miller 2013) and is unique among eastern North American records in its distance from human development.

Three subspecies of Claytonia perfoliata are recognized in most recent treatments, diagnosable to various extents by cauline and basal leaf morphology, ploidy level, and foliage color. Based on the Flora of North America and the Jepson eFlora (Miller 2003; Miller \& Chambers 2019), this specimen can be classified as C.

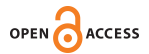

This article has been licensed as Open Access by the author(s) and publisher. This version supersedes any other version with conflicting usage rights. 

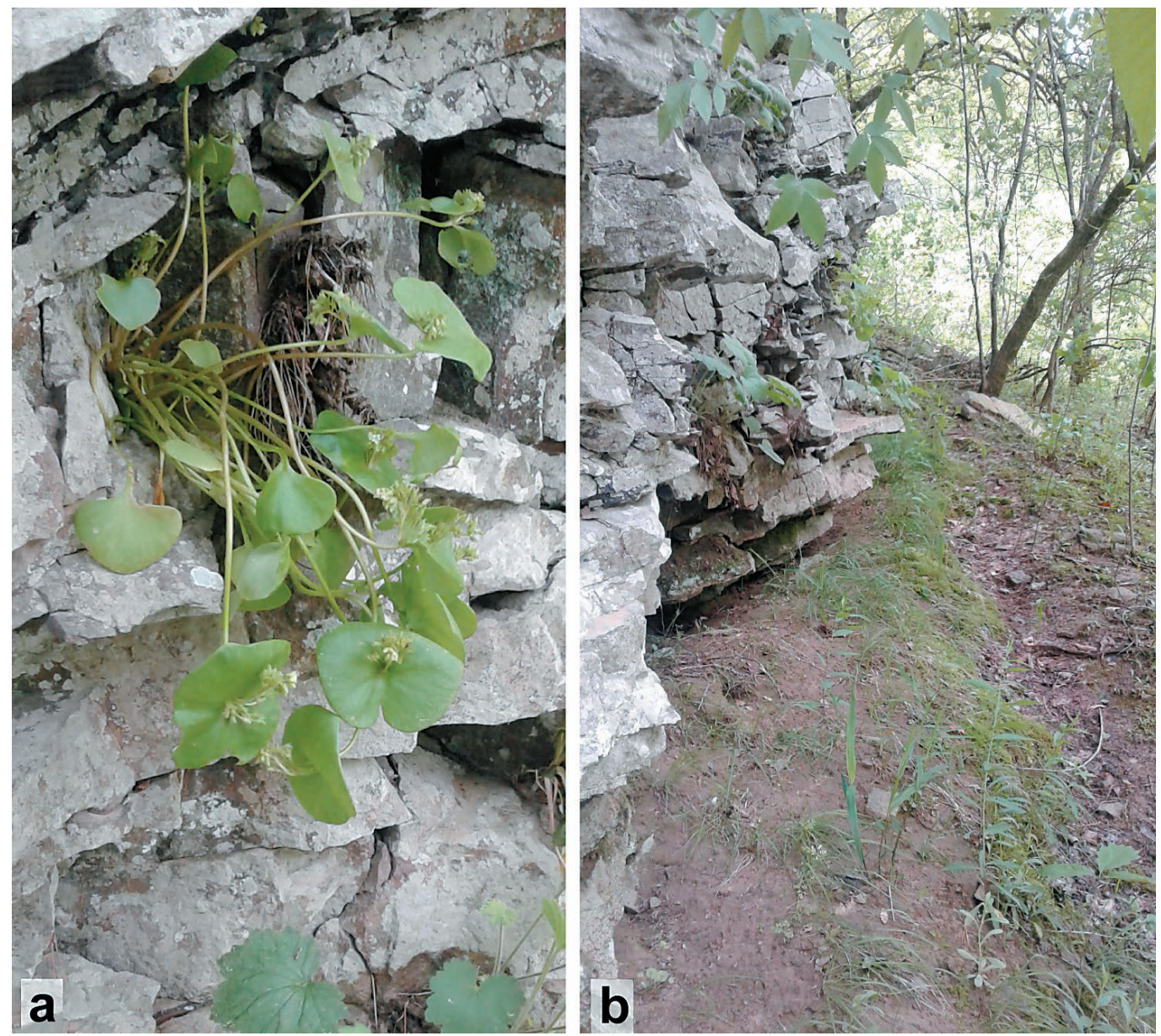

FIG. 1. Cove Creek Natural Area, Arkansas, on 27 April 2019. (a) Claytonia perfoliata subsp. perfoliata (Schneider 1063) immediately before collection. (b) Local habitat, facing north from collection site.

perfoliata subsp. perfoliata by virtue of its rounded basal leaf tips, mostly entire cauline leaves, generally larger rosette, and low levels of red betalin pigments. However, these traits are highly variable and environmentally plastic (Miller \& Chambers 2006). From a phylogenetic perspective, infraspecific taxa within C. perfoliata do not represent monophyletic groups, but rather represent complex, repeatedly evolved allo- and autopolyploid series (Miller \& Chambers 2006; Rausch 2008). Thus, genetic or cytological data would be necessary to fully assess infraspecific relationships, particularly considering that this record is geographically isolated and well outside its typical range.

KEY TO SPECIES OF CLAYTONIA IN ARKANSAS

1. Cauline leaves perfoliate; flowers $<10 \mathrm{~mm}$ diameter; plant annual

C. perfoliata

1. Cauline leaves petiolate or sessile but not perfoliate; flowers $>10 \mathrm{~mm}$ diameter; plant perennial.

2. Cauline leaves linear, sessile or sub-sessile, tapered to slender base; inflorescences unibracteate

C. virginica

2. Cauline leaves ovate to rhombate, distinctly petiolate; inflorescences multibracteate C. arkansansa 


\section{ACKNOWLEDGMENTS}

Thanks to Brent Baker and Brett Serviss for their constructive feedback on this report and Arkansas Natural Heritage Commission for site access and collecting permission (Permit \# S-NHCC-19-003).

\section{REFERENCES}

Gentry, J.L., G.P. Johnson, B.T. BAKeR, C.T. WitselL, \& J.D. Ogle. 2013. Atlas of the vascular plants of Arkansas. University of Arkansas Herbarium, Fayetteville, Arkansas, U.S.A.

INAturalist. 2019. Available at www.inaturalist.org. Accessed 14 September 2019.

MiLleR, J. 2003. Claytonia. In: Flora of North America Editorial Committee, eds. 1993+. Flora of North America north of Mexico. 20+ vols. New York, U.S.A., and Oxford, U.K. 4:465-475.

Millek, J. \& K.L. Chambers. 2006. Systematics of Claytonia (Portulacaceae). Syst. Bot. Monogr. 78:1-236.

MilLER, J. \& K.L. ChAmBERs. 2019. Claytonia. In: Jepson Flora Project, eds. Jepson eFlora, http://ucjeps.berkeley.edu/eflora/ eflora_display.php?tid=8893. Accessed 28 June 2019.

RausCH, J.H. 2008. The evolution of selfing, inbreeding depression, and polyploidy in the Claytonia perfoliata complex (Portulacaceae). Ph.D. dissertation, Washington State University, Pullman, Washington, U.S.A. 